NBER WORKING PAPER SERIES

\title{
HEARD IT THROUGH THE GRAPEVINE: \\ DIRECT AND NETWORK EFFECTS OF A TAX ENFORCEMENT FIELD EXPERIMENT
}

\author{
William C. Boning \\ John Guyton \\ Ronald H. Hodge, II \\ Joel Slemrod \\ Ugo Troiano \\ Working Paper 24305 \\ http://www.nber.org/papers/w24305 \\ NATIONAL BUREAU OF ECONOMIC RESEARCH \\ 1050 Massachusetts Avenue \\ Cambridge, MA 02138 \\ February 2018
}

We have benefitted from conversations with Zachary Liscow, Michael Lovenheim, Christian Traxler, and Danny Yagan, and, regarding the data and IRS enforcement processes, with Brian Best, Jeff Butler, Patrick Langetieg, Juan Mendez, Stacy Orlett, and Alex Turk. We also thank Barry Johnson, Michael Weber, and Alicia Miller for facilitating this project through the Joint Statistical Research Program of the Statistics of Income Division of the United States Internal Revenue Service. Boning acknowledges support by the National Science Foundation Graduate Research Fellowship Program under Grant No. DGE 1256260. Slemrod is an IRS employee without pay under an agreement made possible by the Intragovernmental Personnel Act of 1970 (5 U.S.C. 3371-3376). Any opinions and conclusions expressed herein are those of the authors and do not necessarily represent the views of the Internal Revenue Service or the National Science Foundation. All results have been reviewed to ensure that no confidential information is disclosed. All data work for this project involving confidential taxpayer information was done at IRS facilities, on IRS computers, by IRS employees, and at no time was confidential taxpayer data ever outside of the IRS computing environment. The views expressed herein are those of the authors and do not necessarily reflect the views of the National Bureau of Economic Research.

NBER working papers are circulated for discussion and comment purposes. They have not been peer-reviewed or been subject to the review by the NBER Board of Directors that accompanies official NBER publications.

(C) 2018 by William C. Boning, John Guyton, Ronald H. Hodge, II, Joel Slemrod, and Ugo Troiano. All rights reserved. Short sections of text, not to exceed two paragraphs, may be quoted without explicit permission provided that full credit, including $\odot$ notice, is given to the source. 
Heard it Through the Grapevine: Direct and Network Effects of a Tax Enforcement Field Experiment

William C. Boning, John Guyton, Ronald H. Hodge, II, Joel Slemrod, and Ugo Troiano NBER Working Paper No. 24305

February 2018

JEL No. C93,H26,L14

\title{
ABSTRACT
}

Tax enforcement may affect both the behavior of those directly treated and of some taxpayers not directly treated but linked via a network to those who are treated. A large-scale randomized field experiment enables us to examine both the direct and network effects of letters and in-person visits on withheld income and payroll tax remittances by at-risk firms. Visited firms remit substantially more tax. Their tax preparers' other clients also remit slightly more tax, while their subsidiaries remit slightly less. Letters have a much smaller direct effect and no network effects, yet may improve compliance at lower cost.

\author{
William C. Boning \\ University of Michigan \\ Department of Economics \\ 611 Tappan Ave \\ Ann Arbor, MI 48109 \\ wcboning@umich.edu \\ John Guyton \\ Internal Revenue Service \\ Research, Applied Analytics, and \\ Statistics \\ 77 K Street, NE \\ Washington, DC 20002 \\ john.guyton@irs.gov \\ Ronald H. Hodge, II \\ Internal Revenue Service \\ Research, Applied Analytics, and \\ Statistics \\ 77 K Street, NE \\ Washington, DC 20002 \\ Ronald.H.HodgeII@irs.gov
}

\author{
Joel Slemrod \\ University of Michigan \\ 701 Tappan Street \\ Room R5396 \\ Ann Arbor, MI 48109-1234 \\ and NBER \\ jslemrod@umich.edu \\ Ugo Troiano \\ Department of Economics \\ University of Michigan \\ 611 Tappan Street, Lorch Hall 219 \\ Ann Arbor, MI 48109 \\ and NBER \\ troiano@umich.edu
}

An online appendix is available at http://www.nber.org/data-appendix/w24305 
In the canonical Allingham and Sandmo (1972) model of tax evasion, increased enforcement reduces evasion because taxpayers perceive that evasion is more likely to be detected and punished when enforcement is high. Field experiments in cooperation with tax authorities, beginning with the audit threat letters discussed in Blumenthal, Christian, and Slemrod (2001) and Slemrod, Blumenthal, and Christian (2001), and surveyed in Hallsworth (2014) and Slemrod (2016), have enabled substantial progress in understanding the effects of tax enforcement interventions on the treated taxpayers. Yet the focus on targeted taxpayers, usually letter recipients, largely neglects the effectiveness of enforcement as a deterrent to evasion by the majority of taxpayers, who are not themselves targeted but may learn about and react to enforcement changes.

This paper bridges the gap between the responses of targeted taxpayers and the response of the population at large by examining both the direct effect of enforcement on targeted taxpayers and the network effects of enforcement. Specifically, we examine the response of taxpayers who are linked to targeted taxpayers by a shared tax preparer, common geographic neighborhood, or parentsubsidiary relationship. The network effects capture word-of-mouth spread of information about enforcement, one mechanism by which general perceptions about enforcement can change. Understanding the flow of information through networks could improve the cost-effectiveness of enforcement policy, for example treating taxpayers with the most network links increases voluntary compliance in the agent-based model of Andrei, Comer, and Koehler (2014). Enriching our understanding of network effects could be valuable beyond tax policy, as the role of networks in social interactions is a burgeoning area of research in several fields, surveyed by Jackson (2010).

We study both network and direct effects in a large-scale field experiment conducted by the IRS, in which 12,172 firms suspected to be noncompliant were assigned either to one of two treatment arms or to a control group. The experiment 
was designed to examine employer compliance with the requirement to remit withheld income taxes and payroll taxes, an area of compliance that has gone relatively unstudied despite its prominence in modern tax systems - these remittances by employers amounted to 70 percent of the total tax collected by the Internal Revenue Service in 2016 (IRS 2017). One treatment was an informational letter, while the other was a much more dramatic intervention, an in-person visit to the place of business by an IRS Revenue Officer. The direct effect of the Revenue Officer visit was a 276 percent increase in tax remitted by visited taxpayers relative to the control group one quarter after treatment, an effect that remained substantial one year after treatment. Receiving a letter increased remittances by 34 percent for a single quarter.

While receiving the letter did not have significant network effects, receiving a Revenue Officer visit did, increasing tax remitted by 2 percent in the following quarter among the 24 firms, on average, sharing a tax preparer with each visited firm. In contrast, subsidiaries of visited firms reduced their tax remittances by 9.3 percent, a network effect that may reflect reallocation of resources within the enterprise rather than information diffusion.

The few field experiments that test for network effects of tax enforcement focus primarily on geographic connections between households, as opposed to the interfirm links studied in this paper; neither professional preparer nor parent-subsidiary links have previously been examined. Our paper focuses on tax enforcement aimed at firms, which is understudied relative to tax enforcement aimed at individuals. There are two main contributions of the paper. The first is the finding that an inperson Revenue Officer visit is much more effective in increasing tax compliance than a soft letter, which nevertheless increased tax compliance relative to a control group. This finding is consistent with the spillover effects on nearby households of in-person visits by Austrian TV tax inspectors in Rincke and Traxler (2011), although in a population of firms rather than households. 
The second contribution of this paper is building a bridge between the novel literature focusing on firm tax compliance and that focused on estimating network effects of tax enforcement. Meiselman (2016) finds no evidence that sending letters to Detroit city income tax non-filers leads their neighbors to file, while Drago, Mengel, and Traxler (2015) find neighborhood spillovers from mailings sent to Austrian households that are potential evaders of the TV tax. Perez-Truglia and Troiano (2016) find that tax delinquents in three U.S. states react to mailings that increase the salience of possible shaming in the eyes of their neighbors. Pomeranz (2015) is an exception to the focus on household ties. In this case, an audit threat increases the VAT declarations of treated firms' suppliers, but not treated firms' clients. This pattern is consistent with the incentives greater VAT enforcement provides for treated firms to insist that transactions with suppliers are reported, and for treated firms' suppliers to match reports with the treated firm, and is not informative about word-of-mouth diffusion of information. Alstadsaeter, Kopczuk, and Telle (2015) study how information about a legal tax avoidance scheme diffuses.

The paper proceeds as follows: In section 2 we describe the experimental setting and treatments. In section 3 we present the direct effects of our two tax enforcement interventions, the in-person Revenue Officer visit and the soft letter. In section 4 we describe the network effects. In section 5 we discuss the economic significance of the estimates. In Section 6 we describe a conceptual framework to think about the welfare effects of the interventions and the consequences for policy design Section 7 concludes.

\section{Setting and Treatments}

Most U.S. employers are required to file Form 941, "Employer's Quarterly Federal Tax Return,” to report wages and tips, federal income tax withheld, and 
both the employer's and the employee's share of Social Security and Medicare taxes. Between the fourth quarter of 2013 and the fourth quarter of 2014, more than 6.5 million firms filed at least one quarterly Form 941, including subchapter C and S corporations, partnerships, LLCs, and sole proprietorships with employees. The majority of employers are required to make semi-weekly or monthly Federal Tax Deposits (FTDs) of the employment taxes reported on Form 941.

By the end of each calendar quarter, IRS uses an algorithm to identify and prioritize firms at high risk of falling behind on their required deposits into categories called FTD Alerts. For firms with high priority alerts (Alert A or B status), the IRS assigns a Revenue Officer to contact the firm within fifteen days of the alert's issuance. The experiment we study was carried out on a third group of firms, designated as having Alert $\mathrm{C}$ status. These are firms for which the algorithm indicates a higher risk of falling behind on their deposits than the general population, but not as high a risk as firms designated Alert A or B. In some quarters prior to the experiment, Alert $\mathrm{C}$ firms may have received a letter about their deposits. Some, but by no means all, firms receive the same FTD Alert designation for more than one consecutive quarter. ${ }^{1}$ It is especially relevant from a tax enforcement policy standpoint to understand the behavior of Alert $\mathrm{C}$ firms, because these firms are at the margin of field action from the IRS, and are therefore the most relevant population when considering whether to expand or contract the set of firms the IRS contacts.

This paper studies the 12,172 businesses assigned Alert $\mathrm{C}$ status by the algorithm based on payments before and during the fourth quarter of 2014. These firms were randomly assigned to one of three groups. A control group received no FTD Alertrelated contact. A second group received a letter, referred to henceforth as the "soft

1 Due to high turnover from quarter to quarter (e.g., only 28 percent of control group firms continue to have the Alert C designation after one quarter), we expect that a few of the firms randomly assigned in the experiment we study would have received an enforcement action prior to the experiment because of an earlier Alert status. Random assignment makes this fact unlikely to bias our results, although it is relevant when considering how our results generalize to other contexts. 
letter" treatment ${ }^{2}$, early in the first quarter of 2015. The letter notes that the firm's deposits have decreased, discusses the firm's deposit responsibility and potential penalties, and provides information and resources about federal tax deposits and their payment. The third group of firms received an initial in-person contact at the place of business from an IRS Revenue Officer ${ }^{3}$. Initial contact procedures emphasize providing the taxpayer with information about the collection process, discussing the taxpayer's deposit compliance status, and gathering basic information. In some cases, a Revenue Officer may use information from an initial contact to determine that further investigation or contact is warranted, following collection procedures.

Compared to the average firm filing a quarterly employment tax return, firms with Alert C status as of the fourth quarter of 2014 had more employees but remitted less tax and were more likely to have not remitted any tax at all, as Table 1 illustrates. Prior to treatment, the two treatment groups and control group had the same median number of employees, and statistically indistinguishable mean numbers of employees. The pre-treatment mean dollar amounts remitted have large standard deviations and differ substantially across groups due to a handful of extremely large firms. Taking the log of payments plus one dollar results in a less noisy measure that is similar across treatment groups. ${ }^{4}$ In each of five quarters prior to treatment, the fraction of firms remitting any tax and the mean of log(tax remitted +1 ), presented in Figures 1 and 2, are nearly identical across treatment groups. Absent effect heterogeneity, the outcome $\log (\operatorname{tax}$ remitted +1$)$ corresponds to specifying that the response to treatment is proportional to firm size, rather than a fixed dollar amount.

\footnotetext{
${ }^{2}$ A copy of the letter is included in the online appendix. If a taxpayer has filed a form giving a representative power of attorney, the representative also receives a copy of any written correspondence.

${ }^{3}$ IRS records indicate that Revenue Officers dedicated time to contacting nearly all assigned firms.

${ }^{4}$ Results discussed below are robust to instead using the inverse hyperbolic sine transformation, equal tolog $y+$ $\left.\left(y^{2}+1\right)^{1 / 2}\right)$, or winsorizing $\log (y+1)$ at the $99^{\text {th }}$ percentile.
} 
For all treatment groups, tax compliance falls sharply over the four quarters prior to treatment, and even the control group remits more tax one quarter after treatment, a pattern analogous to the "Ashenfelter dip" discussed by Heckman and Smith (1999) in the context of labor market interventions, wherein those who qualify for job training often have temporarily depressed earnings that tend to revert upward toward their longer-term mean even absent treatment. Without an experimental control group, it would be difficult to construct a control group from observational data that would not overestimate the effect of treatment.

\section{A. Follow-up Treatment}

Recent work by Bhargava and Manoli (2015) and Guyton et al. (2016) has shown that enforcement treatments tend to have short-lived effects on taxpayer behavior and that reminders, essentially follow-up rounds of treatment, can boost the persistence of the treatment's effect. This inspired a novel (in the context of tax administration research) feature of the design of this experiment, drawing on practice in medicine-where patients who are initially unresponsive to treatment may receive continued treatment ${ }^{5}$.

At the end of the quarter during which treatment took place, the algorithm that determines whether firms are designated high risk (Alert $\mathrm{C}$ ) ran again, and some of the 12,172 firms in the experiment were again designated high risk. Firms that were again designated high risk received a second dose of their assigned treatment in the following quarter. Thus, each firm assigned, for example, to the Revenue Officer visit group received one visit early in Q1 2015 and, if the firm remained at high risk based on its payments through week twelve of Q1 2015, it received a second Revenue Officer visit in the second quarter of 2015. The same procedure was followed with the letter treatment. After the second quarter, no firm received further

\footnotetext{
${ }^{5}$ See, for example, Zonder et al. (2003) on leukemia and Diehl et al. (2003) on treatment of refractory Hodgkin's lymphoma with a second course of high-dose chemotherapy.
} 
experimental treatment, although some businesses in the experiment might have been assigned to very high risk (Alert A or B) status and thereby been subject to routine enforcement action. Table 2 presents a chronology of treatment.

Turnover in high risk status, detailed in Table 3, is large - only 28 percent of control group firms remained in this category one quarter after random assignment. Among firms assigned to receive a soft letter, 28 percent continued to have high risk status in the following quarter and received a second letter. Among firms assigned to receive a Revenue Officer visit, just 19 percent continued to have high risk status in the next quarter and therefore received a second visit. The lower fraction of firms assigned to receive a Revenue Officer visit continuing in high risk status is consistent with the result, detailed below, that the Revenue Officer visit dramatically increased remittances.

This follow-up treatment allows us to assess the effects of a realistic treatment protocol in which recalcitrant cases receive a follow-up intervention. If the treatment interventions we study were to become standard practice, follow-up treatment of unresponsive firms might well become tax administration procedure. In our analysis, all firms are included regardless of follow-up treatment, but results should be interpreted in light of the follow-up treatment administered to firms whose remittance behavior continued to indicate high risk. Beginning two quarters after treatment, effects capture both the persistent component of the initial treatment administered to all firms in the treatment group and the effect of the follow-up treatment administered one quarter later to a subset of treatment group firms.

\section{Direct Effects}

\section{A. Event Study Regression Design}


While cross-sectional comparisons would also be valid because firms are randomly assigned to treatment ${ }^{6}$, our preferred specification uses an event-study regression design to reduce residual variance and allow for a flexible time path of the treatment response. This design rests on the assumptions that there are no contemporaneous changes that affect the treatment and control groups differentially, and that absent treatment the time paths of the outcome variables in the treated and control groups would evolve in a parallel fashion. ${ }^{7}$ There were no contemporaneous IRS policy changes that might affect the treatment groups differentially. Figures 1 and 2 illustrate that the trends in the outcomes we study are the same across treatment groups for several quarters prior to treatment, which supports the assumption that these trends would continue to be parallel absent the experiment. We estimate models of the form

$$
Y_{i t}=\sum_{j} \sum_{q} \beta_{j q} 1\left(T_{i}=j\right) 1(t=q)+\mu_{i}+\eta_{t}+e_{i t},
$$

where $Y_{i t}$ denotes the outcome of interest, e.g. the log amount of employment tax that firm $i$ remitted with Form 941 in quarter $\mathrm{t}, \beta_{j q}$ is the coefficient that indicates the direct effect of treatment $j$ on the outcome $q$ quarters after treatment, $1\left(T_{i}=\right.$ $j$ ) is an indicator variable equal to one if firm $i$ received treatment $j, 1(t=q)$ is an indicator equal to one if $t$ is $q$ quarters after treatment, $\mu_{i}$ is a fixed effect for firm $i, \eta_{t}$ is a fixed effect for quarter $\mathrm{t}$, and $e_{i t}$ is the regression error term. Standard errors are clustered at the firm level to account for possible serial correlation in the error term. The two outcomes we study are log(employment tax remitted +1 ) and the probability of remitting any employment tax, for which we use a linear probability model.

\footnotetext{
${ }^{6}$ The results of a cross-sectional comparison, which differ little from the event study results, are reported in the online appendix.

${ }^{7}$ In the online appendix we report results including the five quarters prior to treatment as a placebo test, which shows that neither treatment has a statistically significant effect at the $\mathrm{p}<0.05$ level in any pre-treatment quarter, although the soft letter effect on both outcomes is statistically significant at the $\mathrm{p}=0.10$ level in the period four quarters prior to treatment, perhaps due to chance.
} 


\section{B. Direct Effects Results}

The Revenue Officer visit has large, statistically significant direct effects on both $\log (\operatorname{tax}$ remitted +1$)$ and the probability of remitting any tax throughout the four post-treatment quarters in our sample period. The estimated effect on $\log (\operatorname{tax}$ remitted +1 ) one quarter after treatment, shown in Table 4, is $132.5 \log$ points, a 276 percent increase ${ }^{8}$. Despite the follow-up treatment of $18 \%$ of treated firms after one quarter, the effect diminishes with each successive quarter to 68.5 log points four quarters after treatment, or a 98 percent increase. The effect of the Revenue Officer visit on the probability of remitting any tax in a linear probability model is 12.9 percentage points one quarter after treatment, shrinking with each quarter to 6.9 percentage points four quarters after treatment. For reference, 58 percent of control group firms remitted any tax one quarter after treatment. These effect estimates demonstrate that visited firms had a dramatically larger rebound in compliance after treatment than the control firms, although the control firms also increased compliance slightly after treatment, consistent with mean reversion and the aforementioned Ashenfelter dip. The rebound experienced by control firms suggests that observational studies comparing firms receiving a visit or letter to firms selected from the general population would likely overstate the effects of the compliance treatments, and further indicates the value of conducting randomized experiments.

The estimated effects of the soft-letter treatment on both $\log (\operatorname{tax}$ remitted +1$)$ and the probability of remitting any tax are much smaller. The effect of the soft letter on $\log (\operatorname{tax}$ remitted +1$)$ one quarter after treatment is 29.1 log points, corresponding to a 33.7 percent increase, and is highly statistically significant. Although the point estimates remain between 10 and 15 log points until four

${ }^{8}$ As $e^{1,325}-1=2.76$. 
quarters after treatment, this effect is not statistically significant beyond the first quarter. On the extensive margin of tax compliance, the effect of the soft letter on the probability of remitting any tax is 3.02 percentage points one quarter after treatment, which is highly statistically significant. Point estimates in the following three quarters are between 1 and 1.6 percentage points, and statistically insignificant.

In sum, an in-person Revenue Officer visit causes taxes remitted to more than triple immediately, while a soft letter causes taxes remitted to immediately increase by one-third. The combined effect of the initial visit and a follow-up procedure in which continually non-compliant firms receive a second visit almost doubles taxes remitted even four quarters after treatment began. A similar procedure with soft letters does not significantly increase taxes remitted beyond the first quarter after treatment began. While we cannot isolate the additional causal effect of receiving a second follow-up treatment, the effects of both the visit(s) and letter(s) peak in the first quarter after treatment, prior to the administration of the follow-up treatment to firms that remained high-risk.

\section{Network Effects}

We now turn our focus from the direct, or specific, effect on those firms that themselves receive the enforcement intervention to the network deterrent effect, which operates through contact with those firms directly receiving the enforcement intervention. ${ }^{9}$ As discussed earlier, this analysis could provide insight about how information regarding enforcement actions diffuses to alter the generally perceived probability that tax evasion will be detected. Even if the per-linked-firm network effect is small, a large number of linked firms per treated firm can still result in a

9 While some experimental group firms are linked to one another, raising the concern that network effects could bias direct effects estimates, our direct effect estimates are substantively unchanged when we control for the presence of network effects. These results are reported in the online appendix. 
substantial aggregate effect of network connections on total remittance behavior. Understanding the information network structure could also inform the design of information campaigns, as models show higher voluntary compliance results from providing information to taxpayers with the most links (Andrei, Comer, and Koehler, 2014).

We define two measures of geographic networks, in which firms are linked via business addresses as reported to the IRS prior to treatment either through a shared ZIP Code or, at a more fine-grained level, a shared ZIP+4. The 42,000 five-digit ZIP Codes in the United States indicate a shared postal facility and are assigned to either geographic areas or post office boxes (USPS, 2016). Firms in our experimental sample share a ZIP Code with an average of $659^{10}$ other employers filing quarterly employment tax returns. A ZIP+4 is a nine-digit designation for a small group of blocks or segment of a postal route (USPS, 2016). Each firm in our experimental sample shares a ZIP+4 with an average of just 3 other firms filing quarterly employment tax returns.

We also explore linkages via a shared tax preparer or tax preparation firm. Each individual tax preparer has a unique Preparer Tax Identification Number (PTIN), which that preparer includes on each return he or she prepares. If the preparer is part of a tax preparation firm, the firm's unique Employer Identification Number (EIN) is also included on each prepared return. These identifiers allow us to identify when two firms' returns are prepared by the same individual preparer or by preparers working at the same tax preparation firm. We consider two firms linked to a tax preparer or tax preparation firm if that tax preparer or tax preparation firm prepared at least one Form 941 for that firm in the four quarters prior to treatment; it is plausible that firms might have contact with a tax preparer or tax preparation firm they have used in the past year even if they are no longer using that preparer,

\footnotetext{
${ }^{10}$ As some firms are linked to more than one Alert $\mathrm{C}$ firm, the sample of firms linked by ZIP code to Alert $\mathrm{C}$ firms is smaller than 659 times the size of the Alert C sample, and similarly for the other network channels we study.
} 
if they are concerned about IRS enforcement action related to past filings. Each firm in our experimental sample shares a tax preparer with an average of 23 other firms filing Form 941 and a tax preparation firm with an average of 98 other firms filing Form 941.

Finally, we investigate links between parent corporations and their subsidiaries. Parent/subsidiary relationships meet one of two sets of criteria in the year prior to treatment assignment. In the first case, the parent corporation files IRS Form 851, “Affiliations Schedule,” with a consolidated group annual tax return indicating that the parent owns stock with 80 percent or more of both the total value and voting power of the subsidiary directly or indirectly through other corporations in the consolidated group. In the second case, the parent corporation is a subchapter $\mathrm{S}$ corporation and has filed Form 8869, electing to treat a domestic corporation whose stock it wholly owns as a qualified subchapter S subsidiary which is deemed liquidated. This definition implies that firms have at most one parent and that parent firms cannot themselves have a parent, as parents in our sample are either the ultimate parent of a consolidated group or $\mathrm{S}$ corporations whose owners are required by law to be individual people. The business operations of the parent and subsidiary are presumably tightly linked, given the degree of ownership and filing of a consolidated annual tax return.

The various networks we study capture a diverse range of relationships between firms. For example, the network effect per link to a firm visited by a Revenue Officer may be large for one channel but not others, and the network effect per link to a soft-letter firm need not be large for that channel. One might expect that soft letters have network effects through ZIP and ZIP+4, as these links capture both geographic proximity and shared postal delivery, while Revenue Officer visits might have especially strong effects through shared preparers or tax preparation firms, as the preparer or firm may interact directly with the Revenue Officer. Additionally, links to Revenue Officer visited firms through a given channel, for 
example a shared preparer, may affect firm behavior on only the intensive margin, captured by our measures of the amount of tax remitted, or only the extensive margin, captured by the tax remitted $>0$ indicator.

\section{A. Controlling for selection bias in estimating network effects}

We aim to identify the causal network deterrence effects of the letter and visit treatments. Specifically, we are interested in the difference between a firm's compliance behavior if its network "neighbors" happen to receive a letter or visit and that firm's behavior if its network neighbors happen to receive no treatment. It is important to keep in mind that simply comparing the post-treatment behavior of firms with network neighbors that received a letter or visit to the post-treatment behavior of all firms without treated network neighbors would provide a biased estimate of the network effect. This is because having treated network neighbors requires having network neighbors with high-risk (Alert C) status, and network links are not random.

Firms with Alert C status are less likely than other employers to have remitted any Form 941-related tax, as Table 1 shows, and so it is natural to suppose that the network neighbors of firms with Alert $\mathrm{C}$ status might have systematically different remittance behavior compared to other firms' network neighbors. For example, if adverse local economic shocks make firms in a neighborhood less likely to remit tax payments, firms in that neighborhood are both more likely to have Alert $\mathrm{C}$ status themselves and more likely to be linked to firms with Alert C status. The same concern arises for links through preparer networks; within a geographical area, it is plausible that a certain type of business is attracted to particular preparers, perhaps because these preparers are known to be more experienced (or more sympathetic, or more condoning) in dealing with at-risk businesses. Parents and their subsidiaries are also likely to share similar compliance behavior. 
We address the selection bias concern by comparing firms with the same number of Alert C neighbors. Consider the example of two firms, each sharing its own unique ZIP Code with exactly one Alert C firm in the experimental sample. Prior to random assignment, the likelihood of each firm sharing its ZIP Code with a firm that receives a Revenue Officer visit is $1 / 3$. Conditional on the number of links to Alert C firms, network treatment is randomly assigned and thus independent of firms' characteristics and potential compliance outcomes. Comparing firms with the same number of links to Alert $\mathrm{C}$ firms allows us to identify an unbiased causal effect of being linked to a treated firm.

The regression approach we implement is a generalized version of the eventstudy approach used above to study direct effects, where we pool firms with different numbers of links to Alert $C$ firms to produce a single treatment estimate, but control for differential patterns of compliance over time between firms based on their total links to Alert $\mathrm{C}$ firms. ${ }^{11}$ This approach relies on the assumption that, conditional on the number of total links to Alert $\mathrm{C}$ firms, the trends in compliance would be parallel across firms linked to different treatment groups absent treatment. Specifically, separately for each network channel $c$ we run regressions of the form:

$$
Y_{i t}=\sum_{j} \sum_{q} \rho_{c j q} L_{c i j} 1(t=q)+\sum_{l} \theta_{c l t}+\mu_{i}+e_{i t},
$$

where $Y_{i t}$ is the outcome for firm $i$ in quarter $t, \rho_{c j q}$ is the network effect through channel $c$ of treatment $j, q$ quarters after treatment, $L_{c i j}$ is the number of links through network channel $c$ that firm $i$ has to firms that received treatment $j, 1(t=$ $q$ ) is an indicator equal to one if $t$ is $q$ quarters after treatment, $\theta_{c l t}$ is a fixed effect common to all firms connected through network channel $c$ to a total of $l$ treated and control firms in quarter $t, \mu_{i}$ is a fixed effect for firm $i$, and $e_{i t}$ is the regression

\footnotetext{
${ }^{11}$ Drago, Mengel, and Traxler (2015), studying Austrian TV tax letters, control for this bias by regressing their outcome variable on the fraction of a taxpayer's network links that are to treated firms and the fraction of a taxpayer's links that are to experimental group firms. Our results are substantively unchanged in a panel version of their specification.
} 
error term. Note that, conditioning on a fixed value of the total number of links to Alert $\mathrm{C}$ firms, this specification is a standard event-study specification with quarter and firm fixed effects. The specification pools the event-study specifications across different numbers of total links to Alert $\mathrm{C}$ firms and constrains the estimated network effect to be linear in the number of links to treated firms. We do this in separate specifications for firms sharing a PTIN, EIN, ZIP Code, or ZIP+4 with an Alert $\mathrm{C}$ firm and for the subsidiaries and parents of Alert $\mathrm{C}$ firms. We cluster the standard errors at the level of the channel used in that specification, e.g. ZIP Code, PTIN, or parent, which addresses correlation in the error term between firms sharing, e.g., a preparer or parent as well as serial correlation in the error term.

\section{B. Individual Tax Preparer (PTIN) Network Effects Results}

The Revenue Officer visit slightly increased remittances of firms sharing an individual tax preparer with a visited firm one quarter after treatment, by an estimated $1.99 \log$ points in the $\log (\operatorname{tax}$ remitted +1$)$ specification in Table 5 . With a standard error of $1.11 \log$ points, this effect is statistically significant at the ten percent level. This corresponds to a two percent increase in taxes remitted. Given the average number of links to firms receiving a Revenue Officer visit, this is an economically substantial effect, as discussed in more detail below. The point estimates in later quarters are also positive and of similar magnitude to the effect one quarter after treatment, but they are not statistically significant. The point estimates of the effect on the probability of remitting any tax for all four quarters after treatment are statistically insignificant, with the largest point estimate, 0.188 percentage points, occurring one quarter after treatment.

Links to a firm receiving a soft letter did not have a statistically significant effect on either the amount of tax remitted or the probability of remitting any tax in any 
quarter after treatment. The estimated effect on $\log (\operatorname{tax}$ remitted +1$)$ one quarter after treatment is $-1.25 \log$ points with a standard error of $1.32 \log$ points.

\section{Tax Preparation Firm (EIN) Network Effects Results}

Neither the letter nor the visit has a statistically significant effect on tax remittances by firms linked to a treated firm through a tax preparation firm. The estimated effect of a link to a visited firm one quarter after treatment is $0.0147 \mathrm{log}$ points with a standard error of $0.857 \log$ points, while the one quarter effect of the soft letter is estimated at $-0.814 \log$ points (standard error 0.931 log points).

\section{Narrow Geographic $(\mathrm{ZIP}+4)$ Network Effects Results}

Neither the effect of sharing a ZIP+4 with a firm receiving a Revenue Officer visit nor the effect of sharing a $\mathrm{ZIP}+4$ with a firm receiving a soft letter is statistically significant one quarter after treatment. Oddly, the effect of ZIP+4 links to soft letter firms is statistically significant only three quarters after treatment for both outcomes, with a negative sign. The effect on $\log (\operatorname{tax}$ remitted +1$)$ is estimated at -11.9 log points (standard error 5.39 log points) and the effect on the probability of remitting any tax is -1.39 percentage points (standard error 6.28 percentage points). The effect on both outcomes is statistically significant at the five percent level. This surprising result can perhaps be explained by the fact that the ZIP+4 specification fails a placebo test in all four quarters prior to treatment, while our other specifications do not fail a placebo test in any quarter prior to treatment. The sign of the point estimate of the ZIP+4 soft letter effects is negative in all quarters prior to and after treatment relative to the omitted quarter immediately prior to treatment, which suggests that the anomaly is due to an issue with the paralleltrends assumption for this specification and may be related to the relatively small sample size of the ZIP+4 links sample. 


\section{E. Geographic (ZIP Code) Network Effects Results}

Sharing a ZIP Code with a firm that receives a soft letter or a Revenue Officer visit does not affect $\log ($ tax remitted +1$)$ or the probability of remitting any tax one quarter after tax. These results are estimated with sufficient precision that the 95 percent confidence interval for the effect of a ZIP Code link to a firm that received a Revenue Officer visit one quarter after treatment spans (-0.00283, 0.00923), ruling out effects with a magnitude of a single log point. The similar confidence interval for the soft-letter ZIP Code network effect is $(-0.00581,0.00565)$, ruling out effects with a magnitude of $0.6 \log$ points. However, even effects small enough to lie within these confidence intervals would have substantial economic implications for the aggregate effect of treatment given the large numbers of firms sharing a ZIP Code with a treated firm, as we discuss in greater detail below.

\section{F. Parent and Subsidiary Network Effects Results}

Next, we consider the effects of a Revenue Officer visit or soft letter on the taxes remitted by the corporate parents and subsidiaries of treated firms. The 12,172 firms in the treatment and control groups include 49 firms with at least one subsidiary. Many of these firms have more than one subsidiary, so that there is a total of 397 subsidiaries. Strikingly, we find that subsidiaries of firms receiving a Revenue Officer visit remit less tax than the subsidiaries of the control firms. The Revenue Officer visit reduces the employment taxes remitted by subsidiaries by $7.53 \log$ points one quarter after treatment, a 9.3 percent decrease, as reported in Table 9. The probability that a subsidiary remits any tax also decreases, by 0.917 percentage points. Both effects are highly statistically significant. The point estimates of the effect of the visit remain negative in the four quarters after treatment, but are statistically insignificant with the exception of the effect on the probability of 
remitting any tax four quarters after treatment, which declines by 7.16 percentage points and is statistically significant only at the $\mathrm{p}<0.1$ level.

The observed decline in subsidiaries' remittances induced by higher enforcement on the parent, which has not been previously documented, has two possible explanations. The first is a cash-flow effect; when the parent is induced to remit more, perhaps in a period of business stress, it relieves the cash strain by reducing tax remittances of firms it controls. This behavior is also broadly consistent with behavior that has been documented in other contexts that increased enforcement attention to one item of taxable income--usually receipts in an income tax--leading to firms increasing their reported expenses, which are less readily monitored, to reduce the impact on tax liability. ${ }^{12}$ We do not find statistically significant effects of the soft letter on subsidiaries' remittance behavior.

In contrast to the effects of enforcement on the subsidiaries of treated firms, we do not find statistically significant effects on the parents of treated firms. Only 33 firms are parents of at least one Alert $\mathrm{C}$ firm; in one case, a parent has two subsidiaries in Alert C. The small size of the parent sample limits the statistical power with which we can examine parent behavior. The estimated effects of both treatments on the parent firm's tax remitted in the quarter after treatment are positive but statistically insignificant. This evidence is consistent with an asymmetric relationship between parents and subsidiaries in which subsidiaries are on average much smaller than parents and as a result more responsive to the parent's enforcement status than vice versa, although effects on parents of a similar magnitude to the effects on subsidiaries are included in a 95\% confidence interval for the effect on parents, so we cannot rule out symmetric effects on parents and subsidiaries.

\footnotetext{
${ }^{12}$ See Carrillo et al. (2017) and Slemrod et al. (2017).
} 
To summarize the network effects results, firms sharing an individual tax preparer with a firm visited by a Revenue Officer remit two percent more tax one quarter after treatment, and subsidiaries of firms visited by a Revenue Officer remit 9.3 percent less tax one quarter after treatment.

\section{How Large Are the Aggregate Network Effects Relative to the Direct Effects?}

The aggregate network effect totaled across all linked firms of an intervention on revenue collected may be non-trivial relative to the direct effect on revenue remitted by the treated taxpayer even if the per-link network effect is much smaller than the direct effect, if there are sufficiently many network links. To explore this issue, we begin by defining the network multiplier to be the aggregate revenue effect of an intervention via a network divided by the intervention's direct effect on revenue.

To obtain the network multiplier we must first convert our estimates into dollars of revenue collected per visit or letter. For the direct effect of the visit, this calculation (reported in Table 11) takes the average amount remitted by an Alert C firm one quarter before treatment (plus one for consistency with our regression specifications), \$39,071, and multiplies by $e^{1.325}-1=2.761$, where 1.325 is the estimated effect of the visit reported in Table 4, to obtain $\$ 107,878$ per visit, with a delta method standard error of $\$ 15,311$. A similar calculation for the letter multiplies $\$ 39,071$ by $e^{0.291}-1=0.338$, again taking the coefficient estimate from Table 4, to obtain $\$ 13,196$ per letter, with a delta method standard error of $\$ 5,237$.

The dollar value of the network effect of the visit through shared preparers begins with the average tax remitted by a firm sharing a preparer with an Alert $\mathrm{C}$ firm one quarter before treatment plus one, $\$ 31,272$, and multiplies by $e^{0.0199 * 1.39}-1=$ 0.03 to obtain $\$ 880$ per linked firm (standard error $\$ 498$ ), where 0.0199 is the estimated effect of a link to a visited firm through a shared tax preparer reported in 
Table 5 and 1.39 is the average number of tax preparer links to Alert $C$ firms among firms with at least one tax preparer link. Multiplying by the average number of linked firms per visited firm, 16.4 , gives $\$ 14,437$ per visit with a standard error of $\$ 8,169$. The network multiplier is then 0.13 , indicating that in aggregate the tax preparer network effect of the visit is 13 percent of the direct effect of the visit.

Performing a similar calculation for the effect on subsidiaries gives a network multiplier of -0.10 . The subsidiaries are on average quite large, remitting $\$ 4,647,756$ one quarter before treatment. The multiplication factor applied is $e^{-0.0753}-1=-0.0725$, where the coefficient estimate is obtained from Table 9 . This gives $-\$ 337,007$ per linked subsidiary but only $-\$ 10,992$ per visit (standard error $\$ 2,252$ ) because there are 0.033 subsidiaries per Alert $C$ firm.

Because the estimated network multiplier of 0.13 for the shared tax preparer network effect is largely offset by the estimated network multiplier of -0.10 for the subsidiary effect, the overall network effect is only 1.03 times the direct effect, $\$ 3,446$ added to the $\$ 107,878$ direct effect. These estimates employ several simplifying assumptions. Using the mean number of tax preparer links per treated firm, instead of the distribution of links. For simplicity, these calculations do not account for effect heterogeneity by firm size, the possibility that responses to multiple links to treated firms are not log-linear, or that some pairs of firms may be connected by more than one of the networks we define and affected by interactions between the effects through multiple networks. Despite these assumptions, the network multiplier calculations demonstrate that network effects may be economically substantial.

\section{Implications for Policy}

How do these findings inform resource allocation decisions? Should each treatment be expanded or cut back? To answer these questions, we need to consider 
all the costs and benefits of each treatment to reach a conclusion its costeffectiveness.

\section{A. Would Net Revenue Rise?}

Assessing the effect on net revenue requires comparing the revenue raised by a treatment to its marginal administrative cost. There are three components to the revenue raised: the direct effect, the network effect, and the general deterrent effect in the population at large, denoted as $r_{D t}, r_{N t}$, and $r_{G t}$, respectively, where subscript $t$ indicates the treatment and is $V$ for visit or $L$ for letter. In this paper, we have estimated the first two of these. The revenue raised should be compared to the marginal administrative cost, denoted $a_{t}$. The calculation for each treatment is simply whether $r_{D t}+r_{N t}+r_{G t} \equiv r_{t}>a_{t}$.

To address these questions, we begin by referring to the dollar values calculated in Table 11, where we show that $r_{D V}=\$ 107,878$ and $r_{D L}=\$ 13,196$. Based on IRS data, $a_{V}=\$ 220$ and $a_{L}=\$ 4$. Both treatments clearly increase net revenue without taking network or general deterrent effects into account. Assuming the general deterrent effect, which we cannot observe, were negligible, incorporating the statistically significant network effects of the visit yields $r_{N V}=\$ 14,437-$ $\$ 10,992=\$ 3,446$. Then $r_{V}=\$ 107,878+\$ 3,446=\$ 111,324>\$ 220$. Similarly, we can calculate that $r_{L}=\$ 13,196>\$ 4$. Both treatments easily pass this simple net-revenue-increasing test.

There are, though, other issues to consider. These calculations ignore compliance costs, which are likely higher for the Revenue Officer visit. In addition, we have ignored any difference between the average effect we have estimated and the marginal effect. Perhaps, most importantly, these calculations should be done on a discounted present-value basis. Given that current interest rates are near zero, discounting itself is not a substantively important issue over the course of a single 
year. What is not known is whether the estimated effects would reverse sign if carried out past the year we examine. In other words, we will be overstating the net revenue gain to the extent that the treatments cause payments to accelerate but not increase in total; we see no sign of this over the course of a year, but cannot be sure it is not an issue over a longer time horizon.

\section{B. Should Resources Be Re-Allocated?}

Should a given amount resources be re-allocated between office visits and letters? If the objective of the tax authority is to maximize revenue net of cost, then the answer depends on whether the following inequality holds: if it does, resources should be shifted from letters to Revenue Officer visits: ${ }^{13}$

$$
r_{D V}+r_{N V}+r_{G V}>\left(\frac{a_{V}}{a_{L}}\right)\left(r_{D L}+r_{N L}+r_{G L}\right) .
$$

In expression (3), $\left(\frac{a_{V}}{a_{L}}\right)$ represents the tradeoff in the extent of alternative treatments: if one less revenue-officer visit is done, $\left(\frac{a_{V}}{a_{L}}\right)$ more letters can be sent out while staying within the given budget. Now the relative general deterrence effects of the two treatments can matter. If we are willing to assume that the general deterrence effects are proportional to the sum of the direct and network effects, then (3) simplifies to:

$$
r_{D V}+r_{N V}>\left(\frac{a_{V}}{a_{L}}\right)\left(r_{D L}+r_{N L}\right)
$$

Using our values from above, the left-hand side of (4) is $\$ 107,878+\$ 3,446=$ $\$ 111,324$, while the right-hand side is $(220 / 4) * \$ 13,196=\$ 725,780$. Because letters deliver about one-eighth of the visit's return for just one $55^{\text {th }}$ of the cost, the average per-dollar-spent return to the letter is much higher and thus a fiscally-

\footnotetext{
${ }^{13}$ All of the point estimates have associated confidence bands, and the cost-benefit analyses are as a result themselves subject to error.
} 
constrained tax agency would increase revenue by shifting resources from visits to letters at the margin. ${ }^{14}$

\section{Would Policy Changes Increase Welfare?}

The evaluation of whether welfare would rise when a given policy changes is more complicated. For one thing, such an evaluation should account for marginal compliance costs (resource costs borne directly by private citizens in the form of time and expenditure), which are social costs that do not show up in government budgets. Second, the appropriate criterion is not whether revenue net of cost increases, because that ignores the fact that any additional tax remittance is a transfer from private hands, which has social value, to the government that provides services that are of value to the population. As shown in Keen and Slemrod (2017), which draws on Slemrod and Yitzhaki (1987) and Mayshar (1991), the welfare impact of the intervention can be approximated by

$$
\Delta W \equiv\left(v^{\prime}-1\right) \Delta R-v^{\prime} \Delta a-\Delta c
$$

In expression (5), $v^{\prime}$ is the marginal social value of an additional dollar of revenue. If the question is whether to increase administrative effort, ceteris paribus, then $v^{\prime}$ represents the marginal social value of raising a dollar of net revenue for public spending. If the question is whether to increase administrative effort while reducing, say, the tax rate in a revenue-neutral way, then $v^{\prime}$ represents the social cost saved by reducing the tax collected via the tax rate by one dollar, sometimes referred to as the marginal efficiency cost of raising funds. In either case, the first term on the right-hand-side of expression (5) is the marginal social value of the

\footnotetext{
${ }^{14}$ Assuming that the average return in our sample equals the marginal return, and that in equilibrium the deterrent effect of the soft letter treatment does not rely on the threat that failure to change course will incur more serious intervention, for example a Revenue Officer visit. This possibility is not addressed by the experiments we conduct, because we do not vary the operational procedure in which populations judged to be higher-risk than our sample receive Revenue Officer visits.
} 
additional net revenue collected when an administrative policy instrument increases by one unit. Because raising revenue is costly, the value of $v^{\prime}$ will exceed one. The other two terms on the right-hand-side of expression (5) are the marginal social cost of increasing government spending and the marginal compliance cost; the former is multiplied by $v^{\prime}$ to reflect that government spending must be funded by raising distortionary, and therefore socially costly, taxation.

To see the implications of expression (5), consider the assumptions in Mayshar (1991), that $v^{\prime}=1.17$ and that the marginal compliance cost is twice the marginal administrative cost. In addition, assume that the general deterrent effect is zero. Then (5) becomes the following expressions for letters and for Revenue Officer visits:

$$
\Delta W_{L}=(1.17-1) * 13,196-1.17 * 4-8=2,228 \gg 0 .
$$

$$
\Delta W_{V}=(1.17-1) * 111,324-1.17 * 220-440=18,229 \gg 0 .
$$

In these calculations, both the letter and the visit are welfare-enhancing. To be sure, these illustrative calculations depend on arbitrary assumptions about the social value of marginal revenue, the marginal compliance cost, and the general deterrent effect of expanding enforcement instruments. The calculations do, though, illustrate the difference between subjecting enforcement initiatives to a net-revenuemaximizing criterion and subjecting enforcement initiatives to a welfaremaximizing criterion.

\section{Conclusion}

This paper uses a randomized experiment to estimate both the change in employment taxes remitted caused by receiving a letter or in-person Revenue Officer visit and the network effect on taxes remitted by firms linked to letter and 
visit recipients by geography, tax preparers, and parent-subsidiary relationships. To our knowledge, no previous research has investigated the effects of tax enforcement on firms sharing a tax preparer with the treated firm or the treated firm's parent or subsidiaries.

We find large immediate effects of the Revenue Officer visits on tax remittance that persist for at least four quarters thereafter and are transmitted through taxpreparer networks. Strikingly, we find that subsidiaries of treated firms remit less tax, which is consistent either with a cash-flow effect or substitution of noncompliance to an apparently less monitored report. The aggregate effect of the decline in payments by subsidiaries is about one tenth the size of the direct effect. Although the per-firm-link tax-preparer network effects are much smaller than the direct effects, their aggregate effect is also about one tenth the size of the direct effect, so that the overall effect of the visit is roughly the same as the direct effect. We find a positive, but substantially smaller and less persistent, direct effect of the soft-letter treatment but no evidence of network effects of this treatment.

Given the empirical results, both treatments pass a net-revenue-increasing criterion. With a fixed tax authority budget, net revenue from one additional dollar of resources spent is higher from soft letters than Revenue Officer visits due to the low relative administrative cost of sending the letters. With some additional assumptions, both treatments also pass a welfare-increasing criterion. 


\section{REFERENCES}

Allingham, Michael G., and Agnar Sandmo. 1972. "Income Tax Evasion: A Theoretical Analysis." Journal of Public Economics 1 (3-4): 323-338.

Alstadsæter, Annette, Wojciech Kopczuk, and Kjetil Telle. 2015. "Social Networks and Dynamics of Tax Avoidance: Evidence from a Well-Defined Norwegian Tax Shelter.” University of Oslo Working Paper.

Andrei, Amanda L., Kevin Comer, and Matthew Koehler. 2014. "An AgentBased Model of Network Effects on Tax Compliance and Evasion.” Journal of Economic Psychology 40: 119-133.

Bhargava, Saurabh, and Dayanand Manoli. 2015. "Psychological Frictions and the Incomplete Take-up of Social Benefits: Evidence from an IRS Field Experiment.” American Economic Review 105 (11): 3489-3529.

Marsha Blumenthal, Charles Christian, and Joel Slemrod. 2001. "Do Normative Appeals Affect Tax Compliance? Evidence from a Controlled Experiment in Minnesota.” National Tax Journal 54 (1): 125-138.

Carrillo, Paul, Dina Pomeranz, and Monica Singhal. 2017. "Dodging the Taxman: Firm Misreporting and Limits to Tax Enforcement.” American Economic Journal: Applied Economics 9 (2): 144-164.

Diehl, Volker, Harald Stein, Michael Hummel, Raphael Zollinger, and Joseph M. Connors. 2003. “Hodgkin’s Lymphoma: Biology and Treatment Strategies for Primary, Refractory, and Relapsed Disease.” ASH Education Program Book 2003 (1): 225-247.

Drago, Francesco, Friederike Mengel, and Christian Traxler. 2015. “Compliance Behavior in Networks: Evidence from a Field Experiment.” IZA Discussion Paper No. 9443.

Guyton, John, Dayanand S. Manoli, Brenda Schafer, and Michael Sebastiani. 2016. “Reminders \& Recidivism: Evidence from Tax Filing \& EITC Participation 
among Low-Income Nonfilers.” NBER Working Paper No. 21904.

Hallsworth, Michael. 2014. "The Use of Field Experiments to Increase Tax Compliance.” Oxford Review of Economic Policy 30 (4): 658-679.

Heckman, James J., and Jeffrey A. Smith. "The Pre-programme Earnings Dip and the Determinants of Participation in a Social Programme. Implications for Simple Programme Evaluation Strategies." Economic Journal 109 (457): 313-348.

Internal Revenue Service. 2017. Internal Revenue Service Data Book, 2016. Washington, DC. Publication 55B. https://www.irs.gov/pub/irs-soi/16databk.pdf.

Jackson, Matthew O. 2010. “An Overview of Social Networks and Economic Applications.” Handbook of Social Economics 1: 511-585.

Keen, Michael, and Joel Slemrod. 2017. “Optimal Tax Administration.” Journal of Public Economics 152: 133-142.

Mayshar, Joram. 1991. “Taxation with Costly Administration.” Scandinavian Journal of Economics 93 (1): 75-88.

Meiselman, Ben S. 2016. “Ghostbusting in Detroit: Evidence on Nonfilers from a Controlled Field Experiment.” University of Michigan Working Paper.

Pérez-Truglia, Ricardo, and Ugo Troiano. 2015. “Shaming Tax Delinquents: Theory and Evidence from a Field Experiment in the United States.” NBER Working Paper 21264.

Pomeranz, Dina. 2015. “No Taxation without Information: Deterrence and SelfEnforcement in the Value Added Tax.” American Economic Review 105 (8): 25392569.

Rincke, Johannes, and Christian Traxler. 2011. "Enforcement Spillovers.” Review of Economics and Statistics 93 (4): 1224-1234.

Slemrod, Joel. 2016. “Tax Compliance and Enforcement: New Research and Its Policy Implications.” University of Michigan Working Paper.

Slemrod, Joel, Marsha Blumenthal, and Charles Christian. 2001. “Taxpayer Response to an increased Probability of Audit: Evidence from a Controlled 
Experiment in Minnesota.” Journal of Public Economics 79 (3): 455-483.

Slemrod, Joel, Brett Collins, Jeffrey L. Hoopes, Daniel Reck, and Michael Sebastiani. 2017. "Does Credit-Card Information Reporting Improve SmallBusiness Tax Compliance?” Journal of Public Economics 149: 1-19.

Slemrod, Joel, and Shlomo Yitzhaki. 1987. "The Optimal Size of a Tax Collection Agency.” Scandinavian Journal of Economics 89: 183-192.

USPS. 2016. “USPS FAQ.” Accessed October 30, 2016. https://faq.usps.com/.

Zonder, Jeffrey A., Pamela Pemberton, Helen Brandt, Anwar N. Mohamed, and Charles A. Schiffer. 2003. “The Effect of Dose Increase of Imatinib Mesylate in Patients with Chronic or Accelerated Phase Chronic Myelogenous Leukemia with Inadequate Hematologic or Cytogenetic Response to Initial Treatment.” Clinical Cancer Research 9 (6): 2092-2097. 
TABLE 1-ALERT C AND FORM 941 POPULATION DESCRIPTIVE STATISTICS ONE QUARTER BEFORE TREATMENT

\begin{tabular}{lccccc}
\hline \hline & No & Soft & Revenue & Overall & $10 \%$ \\
& Treatment & Letter & Officer & Visit C & Sample of \\
& & & & Form 941 \\
Tax Remitted (\$) & 74,441 & 24,452 & 20,479 & 39,070 & 72,927 \\
& $(3506030)$ & $(220610)$ & $(216136)$ & $(1991178)$ & $(5187780)$ \\
Median Tax Remitted (\$) & 2,841 & 2,793 & 2,900 & 2,846 & 2,650 \\
Log(Tax Remitted + 1) & 5.26 & 5.30 & 5.24 & 5.27 & 6.16 \\
& $(4.67)$ & $(4.69)$ & $(4.68)$ & $(4.68)$ & $(4.42)$ \\
Any Tax Remitted & 0.570 & 0.573 & 0.567 & 0.570 & 0.686 \\
& $(0.495)$ & $(0.495)$ & $(0.496)$ & $(0.495)$ & $(0.464)$ \\
Employees & 56 & 38 & 35 & 43 & 37 \\
& $(1190)$ & $(169)$ & $(108)$ & $(683)$ & $(1722)$ \\
Median Employees & 14 & 14 & 14 & 14 & 4 \\
Firms in sample & 3,894 & 4,069 & 4,209 & 12,172 & 648,993
\end{tabular}

Notes: Means reported except where otherwise indicated. Sample standard deviations in parentheses. Form 941 statistics are from a ten percent random sample of all firms filing Form 941 at any point in the prior year. Tax remitted refers to Form 941-related tax deposits during a calendar quarter. Employees is the number of Forms W-2 filed in the calendar year before treatment and so likely overstates the number of employees at any one point in time.

Source: Author calculations.

TABLE 2-TREATMENT CHRONOLOGY

By December 31, 2014

Q4 2014 Alert C status determined by algorithm, treatment groups randomly assigned.

January 1-15, 2015

By March 31, 2015

April 1-15, 2015

Treatment carried out.

Q1 2015 Alert C status determined by algorithm.

Firms receive a follow-up round of their assigned treatment if they have both Q4 2014 and Q1 2015 Alert C status.

TABLE 3-STAtus of RANDOMly Assigned FiRms One Quarter AfTER Treatment

$\begin{array}{cccc} & & \text { Status One Quarter After Treatment } & \\ & \text { Alert A or B } & \text { Alert C } & \text { No Status } \\ \text { RO Visit (\%) } & 2 \% & 19 \% & 78 \% \\ \text { Soft Letter (\%) } & 5 \% & 28 \% & 66 \% \\ \text { No Treatment (\%) } & 5 \% & 28 \% & 67 \%\end{array}$

Note: Alert A or B status reflects higher risk than firms in with Alert C status, and Alert $\mathrm{C}$ status reflects higher risk than the general population of Form 941 filers. All firms with Alert A or B status receive field contact as part of routine procedure. Firms that continued to have Alert $\mathrm{C}$ status one quarter after treatment received a follow-up dose of their initially assigned treatment. Firms with no status one quarter after treatment did not receive a follow-up dose of treatment.

Source: Author calculations.

TABLE 4-DiRECT EFFECTS OF TREATMENTS ON TREATED FIRMS

$\log ($ Tax Remitted +1$) \quad$ Tax Remitted $>0$
Indicator:




$\begin{array}{lcc} & & \text { Linear Probability } \\ & & \text { Model } \\ \text { Revenue Officer Visit * One Quarter Post } & 1.325 & 0.129 \\ & (0.104) & (0.0113) \\ \text { Revenue Officer Visit * Two Quarters Post } & 1.030 & 0.104 \\ & (0.111) & (0.0120) \\ \text { Revenue Officer Visit * Three Quarters Post } & 0.801 & 0.0803 \\ & (0.114) & (0.0122) \\ \text { Revenue Officer Visit * Four Quarters Post } & 0.685 & 0.0694 \\ & (0.117) & 0.0126) \\ \text { Soft Letter * One Quarter Post } & 0.291 & 0.0302 \\ & (0.100) & (0.0110) \\ \text { Soft Letter * Two Quarters Post } & 0.101 & 0.0112 \\ & (0.110) & (0.0118) \\ \text { Soft Letter * Three Quarters Post } & 0.146 & 0.0158 \\ & (0.114) & (0.0122) \\ \text { Soft Letter * Four Quarters Post } & 0.132 & 0.0136 \\ & (0.116) & (0.0125) \\ \text { Firm Fixed Effects } & \text { Yes } & \text { Yes } \\ \text { Quarter Fixed Effects } & \text { Yes } & \text { Yes } \\ \text { Firms } & 12,172 & 12,172 \\ \text { Observations } & 109,548 & 109,548 \\ \text { R-Squared } & 0.0991 & 0.0824\end{array}$

Notes: Standard errors (in parentheses) clustered by firm. The omitted reference quarter is the quarter in which treatment assignment took place, Q4 2014. Tax remitted refers to Form 941-related tax deposits during a calendar quarter.

Source: Author calculations.

TABLE 5-INDIVIDUAL TAX PREPARER (PTIN) NETWORK EFFECTS

\begin{tabular}{lcc}
\hline & Log(Tax Remitted + 1) & $\begin{array}{c}\text { Probability of Remitting Any } \\
\text { Tax: Linear Probability } \\
\text { Model }\end{array}$ \\
PTIN Links to Revenue Officer Visit Firms * & 0.0199 & 0.00188 \\
One Quarter Post & $(0.0111)$ & $(0.00122)$ \\
PTIN Links to Revenue Officer Visit Firms * & 0.00705 & 0.000315 \\
Two Quarters Post & $(0.0135)$ & $(0.00149)$ \\
PTIN Links to Revenue Officer Visit Firms * & 0.0207 & 0.00123 \\
Three Quarters Post & $(0.0169)$ & $(0.00189)$ \\
PTIN Links to Revenue Officer Visit Firms * & 0.0241 & 0.00162 \\
Four Quarters Post & $(0.0207)$ & $(0.00224)$ \\
PTIN Links to Soft Letter Firms * One & -0.0125 & -0.00183 \\
Quarter Post & $(0.0132)$ & $(0.00152)$ \\
PTIN Links to Soft Letter Firms * Two & 0.00425 & -0.000140 \\
Quarters Post & $(0.0142)$ & $(0.00170)$ \\
PTIN Links to Soft Letter Firms * Three & -0.00635 & -0.00201 \\
Quarters Post & $(0.0177)$ & $(0.00216)$ \\
PTIN Links to Soft Letter Firms * Four & 0.00767 & -0.00111 \\
Quarters Post & $(0.0201)$ & $(0.00238)$ \\
Firm Fixed Effects & Yes & Yes \\
Quarter Fixed Effects & Yes & Yes \\
Quarter * Total PTIN Links to Alert C Fixed & Yes & Yes \\
Effects & & \\
Firms & 199666 & 199666 \\
PTIN Clusters & 10219 & 10219 \\
Observations & 1796994 & 1796994 \\
R-Squared & .0047534 & .0049996 \\
& &
\end{tabular}


Notes: Standard errors (in parentheses) clustered by PTIN. The omitted reference quarter is the quarter in which treatment assignment took place, Q4 2014. Tax remitted refers to Form 941-related tax deposits during a calendar quarter.

TABLE 6-TAX PREPARATION FIRM (EIN) NETWORK EFFECTS

$\begin{array}{lcc} & \text { Log(Tax Remitted + 1) } & \begin{array}{c}\text { Probability of Remitting Any } \\ \text { Tax: Linear Probability } \\ \text { Model }\end{array} \\ \text { EIN Links to Revenue Officer Visit Firms * } & & -0.000349 \\ \text { One Quarter Post } & 0.000147 & (0.000943) \\ \text { EIN Links to Revenue Officer Visit Firms * } & (0.00857) & -0.000465 \\ \text { Two Quarters Post } & -0.00349 & (0.00117) \\ \text { EIN Links to Revenue Officer Visit Firms * } & (0.00957) & 0.000129 \\ \text { Three Quarters Post } & 0.00620 & (0.00148) \\ \text { EIN Links to Revenue Officer Visit Firms * } & (0.0126) & 0.000206 \\ \text { Four Quarters Post } & 0.00826 & (0.00185) \\ \text { EIN Links to Soft Letter Firms * One Quarter } & (0.0165) & -0.00109 \\ \text { Post } & -0.00814 & (0.00107) \\ \text { EIN Links to Soft Letter Firms * Two } & (0.00931) & -0.000442 \\ \text { Quarters Post } & -0.00593 & (0.00119) \\ \text { EIN Links to Soft Letter Firms * Three } & (0.0101) & -0.00115 \\ \text { Quarters Post } & -0.00788 & (0.00141) \\ \text { EIN Links to Soft Letter Firms * Four } & (0.0119) & -0.00149 \\ \text { Quarters Post } & -0.0105 & (0.00168) \\ \text { Firm Fixed Effects } & (0.0145) & \text { Yes } \\ \text { Quarter Fixed Effects } & \text { Yes } & \text { Yes } \\ \text { Quarter * Total EIN Links to Alert C Fixed } & \text { Yes } & \text { Yes } \\ \text { Effects } & \text { Yes } & 395929 \\ \text { Firms } & & 9759 \\ \text { EIN Clusters } & 395929 & 3563361 \\ \text { Observations } & 9759 & .0062022 \\ \text { R-Squared } & 3563361 & \end{array}$

Notes: Standard errors (in parentheses) clustered by EIN. The omitted reference quarter is the quarter in which treatment assignment took place, Q4 2014. Tax remitted refers to Form 941-related tax deposits during a calendar quarter.

Source: Author calculations.

TABLE 7-ZIP+4 NETWORK EFFECTS

\begin{tabular}{lcc}
\hline & Log(Tax Remitted + 1) & $\begin{array}{c}\text { Probability of } \\
\text { Remitting Any Tax: } \\
\text { Linear Probability }\end{array}$ \\
Model \\
ZIP+4 Links to Revenue Officer Visit Firms & & 0.00158 \\
* One Quarter Post & 0.0489 & $(0.00540)$ \\
ZIP+4 Links to Revenue Officer Visit Firms & $(0.0526)$ & 0.00225 \\
* Two Quarters Post & 0.0346 & $(0.00554)$ \\
ZIP+4 Links to Revenue Officer Visit Firms & $(0.0525)$ & -0.00302 \\
* Three Quarters Post & -0.0155 & $(0.00631)$ \\
ZIP+4 Links to Revenue Officer Visit Firms & $(0.0571)$ & -0.000572 \\
* Four Quarters Post & 0.0146 & $(0.00734)$ \\
ZIP+4 Links to Soft Letter Firms * One & $(0.0654)$ & -0.00469 \\
Quarter Post & -0.0164 & $(0.00619)$ \\
ZIP+4 Links to Soft Letter Firms * Two & $(0.0560)$ & -0.00748 \\
Quarters Post & -0.0510 & $(0.00536)$ \\
ZIP+4 Links to Soft Letter Firms * Three & $(0.0474)$ & -0.0139 \\
Quarters Post & -0.119 & $(0.00628)$
\end{tabular}


ZIP+4 Links to Soft Letter Firms * Four

Quarters Post

Firm Fixed Effects

Quarter Fixed Effects

Quarter * Total ZIP+4 Links to Alert C

Fixed Effects

Firms

ZIP+4 Clusters

Observations

R-Squared

$\begin{array}{cc}-0.0847 & -0.0123 \\ (0.0629) & (0.00770) \\ \text { Yes } & \text { Yes } \\ \text { Yes } & \text { Yes } \\ \text { Yes } & \text { Yes } \\ & \\ 32305 & 32305 \\ 5916 & 5916 \\ 290745 & 290745 \\ .0101197 & .0104488\end{array}$

Notes: Standard errors (in parentheses) clustered by ZIP+4. The omitted reference quarter is the quarter in which treatment assignment took place, Q4 2014. Tax remitted refers to Form 941-related tax deposits during a calendar quarter.

Source: Author calculations.

TABLE 8-ZIP CODE NETWORK EFFECTS

\begin{tabular}{lcc}
\hline \hline & Log(Tax Remitted + 1) & $\begin{array}{c}\text { Probability of Remitting } \\
\text { Any Tax: Linear Probability } \\
\text { Model }\end{array}$ \\
ZIP Code Links to Revenue Officer Visit & & 0.000318 \\
Firms * One Quarter Post & 0.00317 & $(0.000348)$ \\
ZIP Code Links to Revenue Officer Visit & $(0.00303)$ & -0.0000109 \\
Firms * Two Quarters Post & 0.000639 & $(0.000355)$ \\
ZIP Code Links to Revenue Officer Visit & $(0.00318)$ & -0.000154 \\
Firms * Three Quarters Post & -0.000404 & $(0.000419)$ \\
ZIP Code Links to Revenue Officer Visit & $(0.00400)$ & 0.000160 \\
Firms * Four Quarters Post & 0.00123 & $(0.000445)$ \\
ZIP Code Links to Soft Letter Firms * One & $(0.00406)$ & -0.0000123 \\
Quarter Post & -0.000109 & $(0.000319)$ \\
ZIP Code Links to Soft Letter Firms * Two & $(0.00288)$ & -0.0000987 \\
Quarters Post & -0.00104 & $(0.000329)$ \\
ZIP Code Links to Soft Letter Firms * Three & $(0.00299)$ & 0.000144 \\
Quarters Post & 0.000642 & $(0.000422)$ \\
ZIP Code Links to Soft Letter Firms * Four & $(0.00392)$ & 0.000210 \\
Quarters Post & 0.00157 & $(0.000470)$ \\
Firm Fixed Effects & $(0.00415)$ & Yes \\
Quarter Fixed Effects & Yes & Yes \\
Quarter * Total ZIP Code Links to Alert C & Yes & Yes \\
Fixed Effects & Yes & 3535438 \\
Firms & & 7136 \\
ZIP Code Clusters & 3535438 & $3.18 \mathrm{e}+07$ \\
Observations & 7136 & .0061926 \\
R-Squared & $3.18 \mathrm{e}+07$ &
\end{tabular}

Notes: Standard errors (in parentheses) clustered by ZIP Code. The omitted reference quarter is the quarter in which treatment assignment took place, Q4 2014. Tax remitted refers to Form 941-related tax deposits during a calendar quarter.

Source: Author calculations.

TABLE 9-EFFECTS ON SUBSIDIARIES OF TREATED FIRMS

$\begin{array}{lcc} & \text { Subsidiary's } & \text { Subsidiary's Probability of } \\ & \text { Remitting Any Tax: } \\ & & \text { Linear Probability Model } \\ \text { Revenue Officer Visit * One Quarter Post } & -0.0753 & -0.00917 \\ & (0.0160) & (0.00323) \\ \text { Revenue Officer Visit * Two Quarters Post } & -0.532 & -0.0441 \\ & (0.362) & (0.0309)\end{array}$

Subsidiary's

$0.362)$ ubsidiary's Probability of

Remitting Any Tax:

$-0.00917$

$-0.0441$

(0.0309) 


$\begin{array}{lcc}\text { Revenue Officer Visit * Three Quarters Post } & -0.682 & -0.0532 \\ & (0.441) & (0.0358) \\ \text { Revenue Officer Visit * Four Quarters Post } & -0.828 & -0.0716 \\ & (0.502) & (0.0406) \\ \text { Soft Letter * One Quarter Post } & 0.0979 & 1.63 \mathrm{e}-15 \\ & (0.0785) & (1.76 \mathrm{e}-09) \\ \text { Soft Letter * Two Quarters Post } & -0.216 & -0.0383 \\ & (0.300) & (0.0357) \\ \text { Soft Letter * Three Quarters Post } & -0.297 & -0.0383 \\ & (0.331) & (0.0354) \\ \text { Soft Letter * Four Quarters Post } & -0.276 & -0.0383 \\ & (0.314) & (0.0354) \\ \text { Firm Fixed Effects } & \text { Yes } & \text { Yes } \\ \text { Quarter Fixed Effects } & \text { Yes } & \text { Yes } \\ \text { Firms } & 397 & 397 \\ \text { Parent Clusters } & 49 & 49 \\ \text { Observations } & 3573 & 3573 \\ \text { R-Squared } & 0.0329 & 0.0274\end{array}$

Notes: Standard errors (in parentheses) clustered at the parent level. The omitted reference quarter is the quarter in which treatment assignment took place, Q4 2014. Tax remitted refers to Form 941-related tax deposits during a calendar quarter.

Source: Author calculations.

TABLE 10-EFFeCtS ON PARENTS OF TREATED Firms

\begin{tabular}{lcc}
\hline & $\begin{array}{c}\text { Parent's } \\
\text { Log(Tax Remitted + 1) }\end{array}$ & $\begin{array}{c}\text { Parent's Probability of } \\
\text { Remitting Any Tax: } \\
\text { Linear Probability Model }\end{array}$ \\
Revenue Officer Visit * One Quarter Post & & 0.0889 \\
& 0.706 & $(0.0633)$ \\
Revenue Officer Visit * Two Quarters Post & $(0.584)$ & 0.00198 \\
& -0.135 & $(0.0633)$ \\
Revenue Officer Visit * Three Quarters Post & $(0.579)$ & 0.0455 \\
& 0.385 & $(0.0781)$ \\
Revenue Officer Visit * Four Quarters Post & $(0.752)$ & -0.0435 \\
& -0.557 & $(0.0438)$ \\
Soft Letter * One Quarter Post & $(0.457)$ & 0.0455 \\
Soft Letter * Two Quarters Post & 0.251 & $(0.0458)$ \\
Soft Letter * Three Quarters Post & $(0.371)$ & 0.0455 \\
Soft Letter * Four Quarters Post & 0.273 & $(0.0458)$ \\
Firm Fixed Effects & $(0.356)$ & 0.0455 \\
Quarter Fixed Effects & 0.382 & $(0.0458)$ \\
Firms & $(0.357)$ & $($ omitted) \\
Parent Clusters & 0.0200 & \\
Observations & $(0.0970)$ & Yes \\
R-Squared & Yes & Yes \\
\end{tabular}

Notes: Standard errors (in parentheses) clustered at the parent level. The omitted reference quarter is the quarter in which treatment assignment took place, Q4 2014. Tax remitted refers to Form 941-related deposits of employment taxes. Soft letter * four quarters post omitted from linear probability model due to collinearity.

Source: Author calculations.

TABLE 11-DOLLAR VALUES AND NETWORK MULTIPLIERS 


\begin{tabular}{|c|c|c|c|c|c|c|}
\hline & $\begin{array}{c}\text { Mean } \\
\text { amount } \\
\text { before } \\
\text { treatment + } 1\end{array}$ & $\begin{array}{l}\text { Coefficient } \\
\text { Factor }\end{array}$ & $\begin{array}{l}\text { Dollar } \\
\text { value per } \\
\text { linked } \\
\text { firm }\end{array}$ & $\begin{array}{l}\text { Linked firms } \\
\text { per Alert C } \\
\text { firm }\end{array}$ & $\begin{array}{c}\text { Dollar } \\
\text { value per } \\
\text { visit or } \\
\text { letter }\end{array}$ & $\begin{array}{l}\text { Network } \\
\text { Multiplier }\end{array}$ \\
\hline $\begin{array}{l}\text { Panel A. } \\
\text { Revenue }\end{array}$ & & & & & & \\
\hline Direct Effect & $\$ 39,071$ & 2.761 & $\begin{array}{c}\$ 107,878 \\
(15311)\end{array}$ & 1 & $\begin{array}{c}\$ 107,878 \\
(15311)\end{array}$ & 1 \\
\hline $\begin{array}{l}\text { Effect of Shared } \\
\text { Preparer }\end{array}$ & $\$ 31,272$ & 0.03 & $\begin{array}{l}\$ 880 \\
(498)\end{array}$ & 16.404 & $\begin{array}{c}\$ 14,437 \\
(8169)\end{array}$ & 0.13 \\
\hline $\begin{array}{l}\text { Effect on } \\
\text { Subsidiary }\end{array}$ & $\$ 4,647,757$ & -0.0725 & $\begin{array}{c}-\$ 337,007 \\
(69063)\end{array}$ & 0.033 & $\begin{array}{c}-\$ 10,992 \\
(2252)\end{array}$ & -0.10 \\
\hline Total & & & & & $\begin{array}{c}\$ 111,324 \\
(25733)\end{array}$ & 1.03 \\
\hline \multicolumn{7}{|l|}{ Panel B. Soft } \\
\hline Direct Effect & $\$ 39,071$ & 0.338 & $\begin{array}{c}\$ 13,196 \\
(5237)\end{array}$ & 1 & $\begin{array}{c}\$ 13,196 \\
(5237)\end{array}$ & 1 \\
\hline Total & & & & & $\begin{array}{c}\$ 13,196 \\
(5237)\end{array}$ & 1 \\
\hline
\end{tabular}

Notes: Mean amount before treatment is the mean tax remitted one quarter before treatment in the Alert C population for direct effects or in the relevant linked population for network effects. The coefficient factor is exp(estimated coefficient) -1 for direct effects and subsidiary effect and exp(estimated effect * average number of links to Alert C conditional on at least one link) - 1 for the tax preparer network effect, where the average number of links conditional on at least one link is 1.39. The relevant coefficients come from Table 4 for direct effects, Table 5 for the shared preparer network effect, and Table 9 for the subsidiary effect. Delta method standard errors in parentheses.

Source: Author calculations.

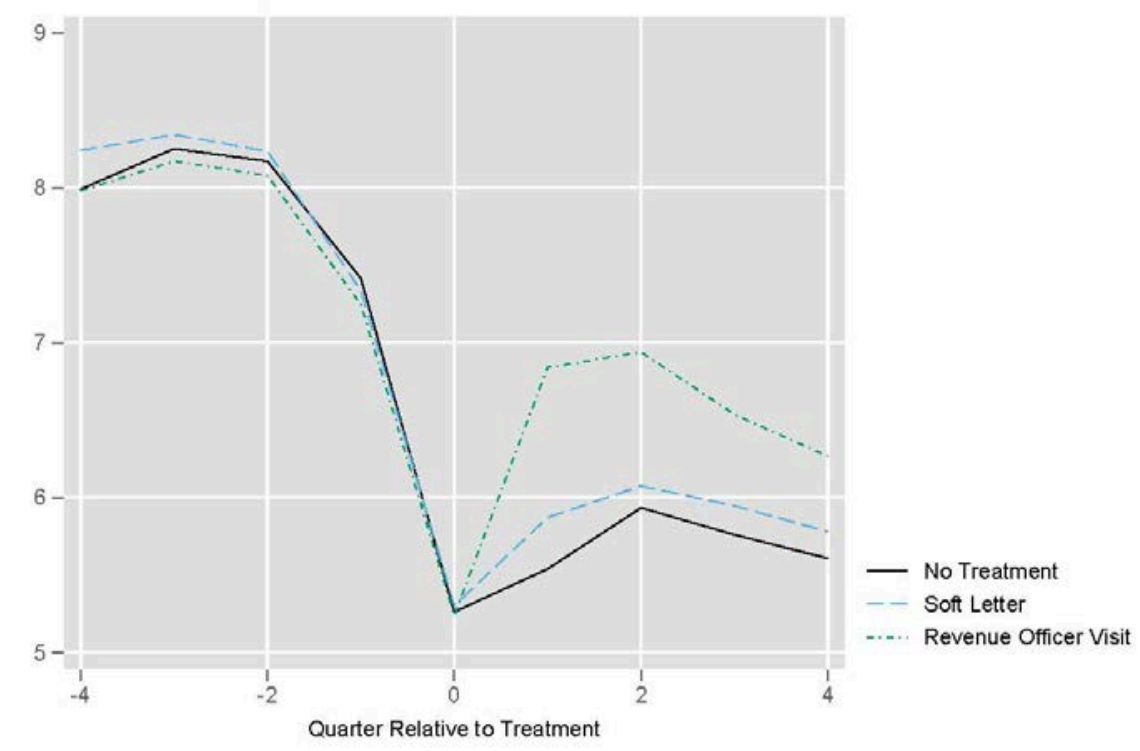

Figure 1. MEAN OF Log(TAX REMITTED + 1) By TREATMENT GROUP

Notes: Tax Remitted is Form 941-related deposits of employment taxes.

Source: Author calculations. 


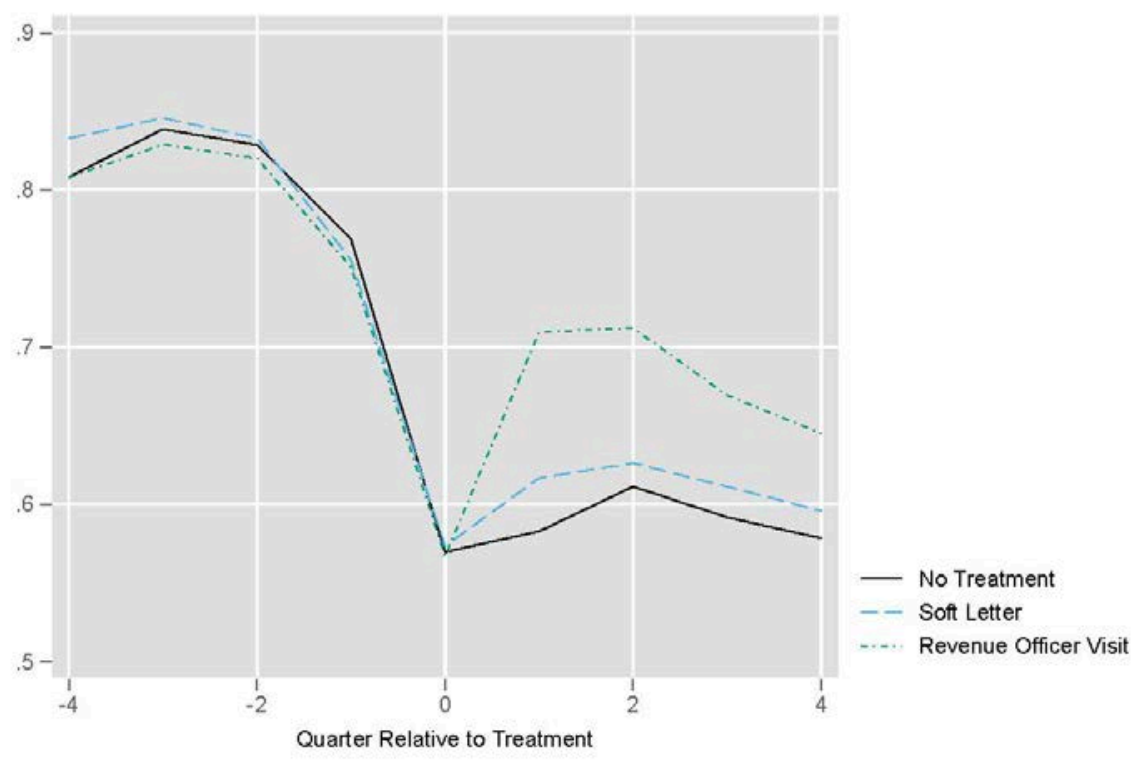

Figure 2. PRoBability of RemitTing ANY TAX By TREATMENT GrouP

Notes: Tax Remitted is Form 941-related deposits of employment taxes.

Source: Author calculations.

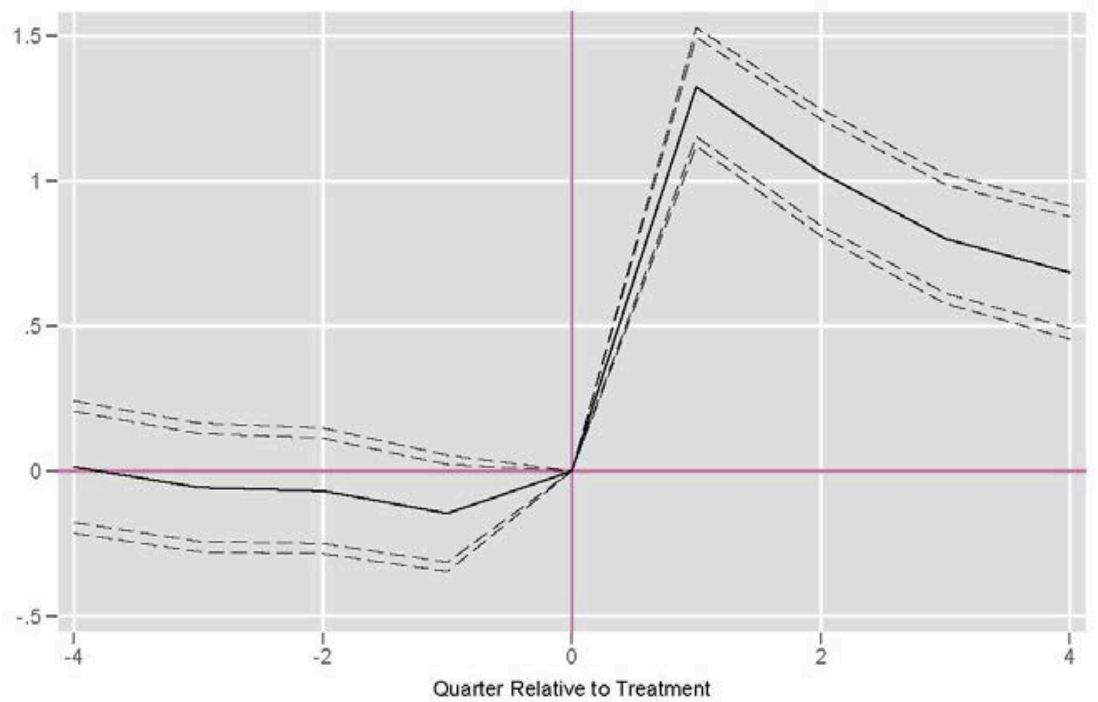

Figure 3. Direct EFFect of ReVEnUe OfFicer Visit on Log(TAX Remitted + 1)

Notes: Dashed lines indicate 90\% and 95\% confidence intervals. Tax Remitted is Form 941-related deposits of employment taxes.

Source: Author calculations. 


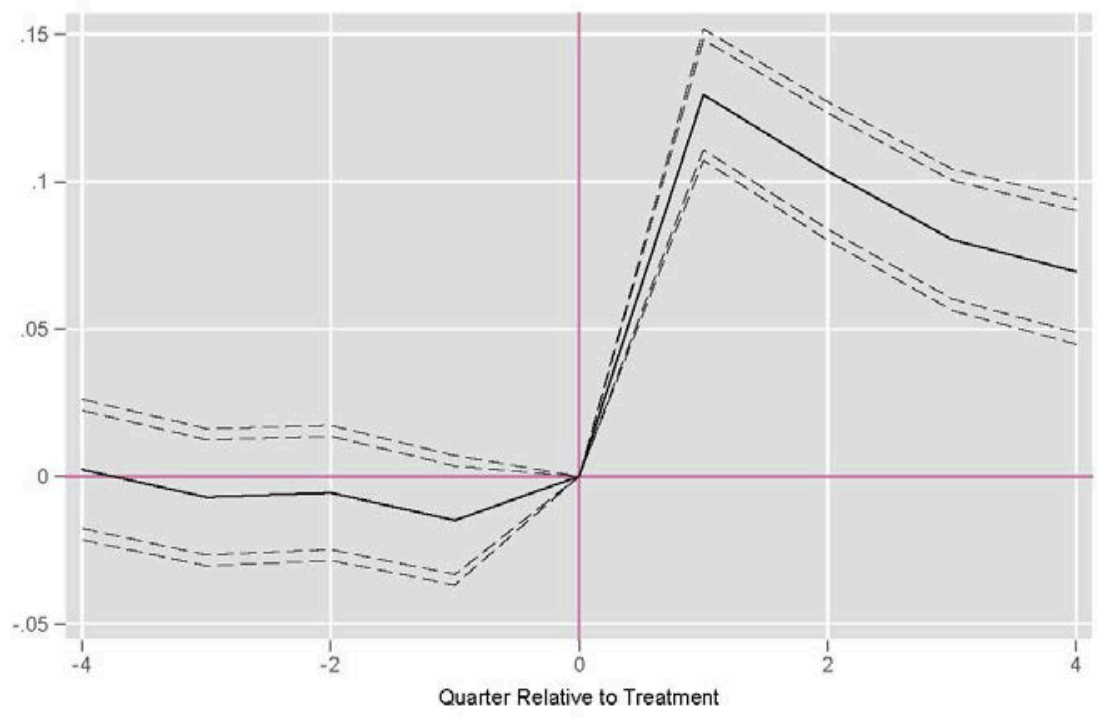

Figure 4. Direct EfFect of ReVEnue OfFicer Visit on Probability of Remitting Any TAX

Notes: Dashed lines indicate 90\% and 95\% confidence intervals. Tax Remitted is Form 941-related deposits of employment taxes.

Source: Author calculations.

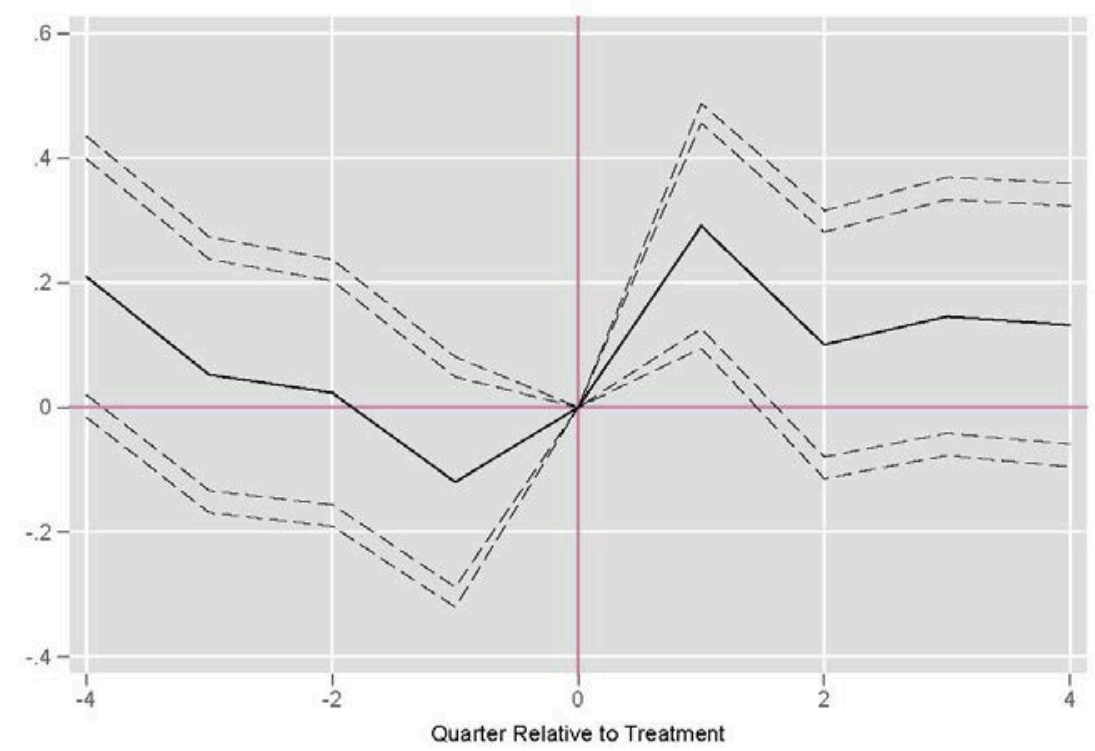

Figure 5. Direct EFFECT OF SOFt LetTER on Log(TAX REMitTed + 1)

Notes: Dashed lines indicate 90\% and 95\% confidence intervals. Tax Remitted is Form 941-related deposits of employment taxes. 
Source: Author calculations.

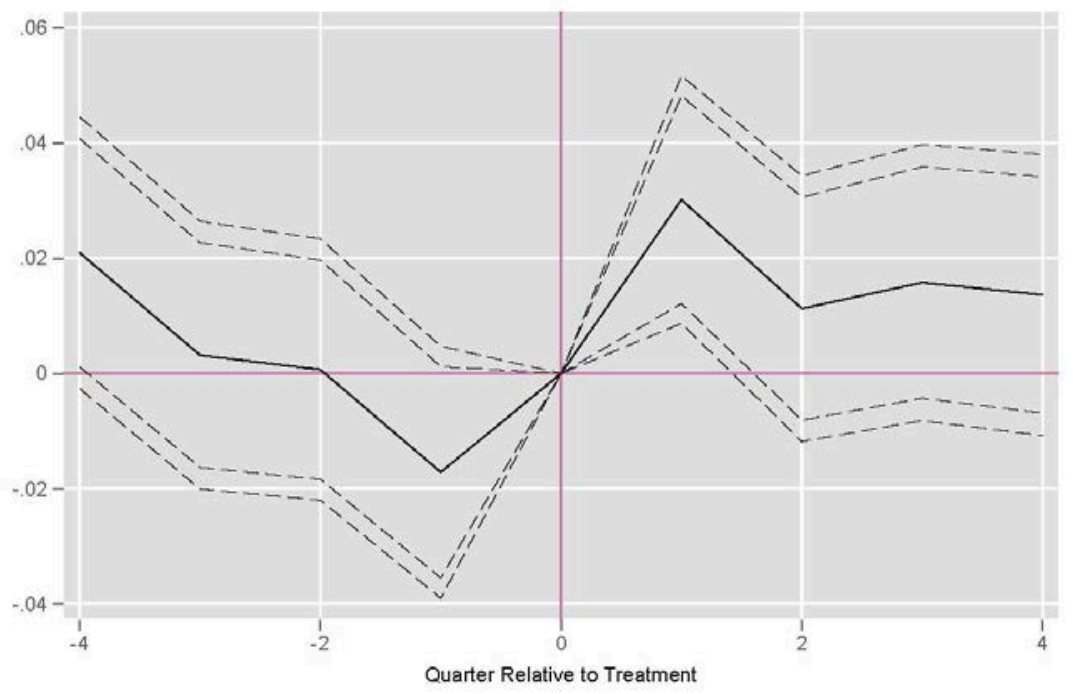

Figure 6. Direct EFFect of SOFt LetTer on Probability of RemitTing ANy TAX

Notes: Dashed lines indicate 90\% and 95\% confidence intervals. Tax Remitted is Form 941-related deposits of employment taxes.

Source: Author calculations. 